\title{
YEMEN'S POST-ARAB SPRING CONFLICT AND ITS RELATIONSHIP WITH THE ECONOMY, POLITICS, AND SAUDI ARABIA'S INFLUENCE IN THE MIDDLE EAST
}

\author{
Ahmad Masyhur ${ }^{1}$ \\ ${ }^{1}$ Universitas Islam Negeri Sunan Kalijaga Yogyakarta \\ 1ªhmadalmasyhur992@gmail.com
}

\begin{abstract}
The ongoing war between the Saudi Arabian coalition and the Houthis has had a significant impact. The participation of Saudi Arabia and its coalition in the middle of the Yemen conflict has a pretext to save the democratically elected official government; however, some argue that Saudi Arabia's participation is more of a sectarian issue. The conflict that is still raging in Yemen at this time is considered very interesting to conduct research, in order to find the true background of the participation of Saudi Arabia and its coalition. Is it true that Saudi Arabia's participation was motivated by a desire to save the official government deposed by the Houthis, or is there another motive at work that is in the best interests of Saudi Arabia and its coalition, such as economic, political, or ideological influence? In this article the researcher uses a qualitative descriptive methodology, qualitative descriptive research in this study will be carried out with several stages including raising a problem, raising research questions, collecting relevant data, analyzing data, and answering research questions. In the investigation, it was found that Saudi Arabia's participation in the Yemeni conflict was inseparable from political, influence and economic interests. Because of the reality that occurred from Saudi Arabia's contradictory attitude toward the Syrian conflict.
\end{abstract}

Keywords: Conflict, Al-Houthi, Yemen, Saudi Arabia, Middle East

$$
\begin{aligned}
& \text { ملخص } \\
& \text { للحرب المستمرة بين التحالف السعودي والحوثيين خسائر كبيرة. إن مشاركة السعودية وتحالفها في خضم الصراع }
\end{aligned}
$$

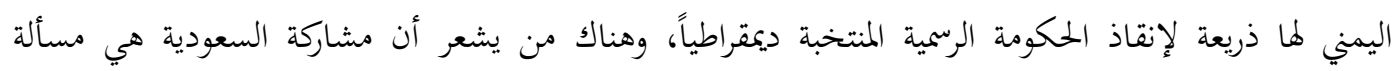

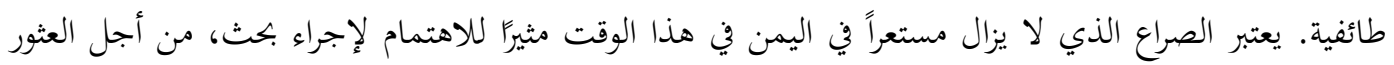

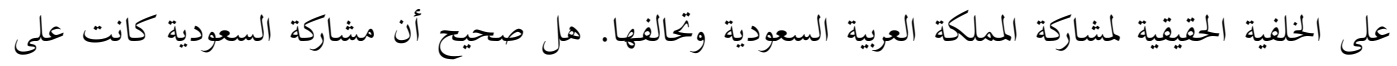

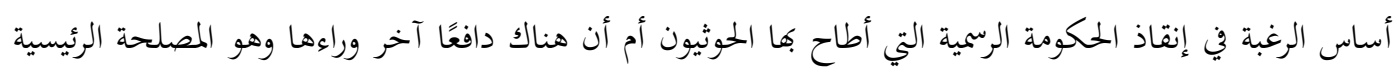

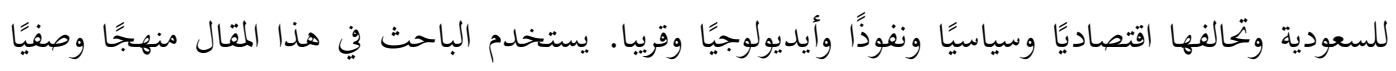

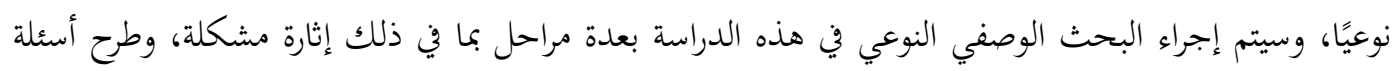

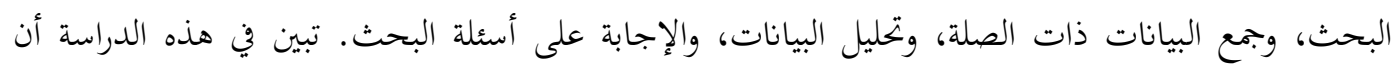

$$
\begin{aligned}
& \text { مشاركة المملكة العربية السعودية في الصراع اليمني كانت لا تنفصل عن المصالح السياسية والنفوذ والمصالح } \\
& \text { الاقتصادية. لأن الواقع الذي حدث انعكس في الموقف المتناقض للسعودية من الصراع الذي حدثن فئن في سوريا. } \\
& \text { الكلمات المفتاحية: الصراع ، الحوثي ، اليمن ، السعودية ، الشرق الأوسط }
\end{aligned}
$$




\section{A. Pendahuluan}

Konflik yang mengatasnamakan ideologi, seperti isu Sunni-Syi'ah yang terjadi di banyak negara, baik di kawasan Asia Barat maupun di wilayah lainnya adalah sebagai salah satu bukti betapa dahsyatnya perang yang mengatasnamakan perbedaan pemahaman dari sudut pandang akidah tersebut. Padahal, Sunni dan Syi'ah adalah dua di antara sekte yang berkembang dan tetap eksis sampai dengan saat ini di dalam tubuh agama Islam. Salah satu konflik yang mengatasnamakan Sunni-Syi'ah yang cukup banyak menarik perhatian dunia adalah konflik yang terjadi di Yaman. Lebih tepatnya, ialah konflik yang terjadi antara kelompok bersenjata alHouthi yang berhaluan Syi'ah dengan beberapa kelompok Salafi-Wahabi yang terkonsentrasi di beberapa tempat di Yaman, seperti: Makrib, Damaj, Damar, dan beberapa tempat lainnya.

Al-Houthi, sebagai salah satu kelompok bersenjata yang berpusat di provinsi Sha'dah (Yaman bagian utara), cukup memberi pengaruh yang besar di kawasannya. Hal tersebut terbukti dengan bertambah banyaknya pengikut dari kelompok tersebut dari tahun ke tahun. Hingga akhirnya, kelompok bersenjata alHouthi yang dahulu pengikutnya hanya terkonsentrasi di Sha'dah pada akhirnya menyebar di hampir setiap provinsi di Yaman, terutama di wilayah bagian utara (Ahmad Fuadi, 2017: 01).

Pada tahun 2014 M, setelah tumbangnya pemimpin diktator Ali Abdullah Saleh dan kemudian digantikan oleh Wakilnya, yaitu, Abdurrabuh Manshur Hadi. Abdurrabuh Manshur Hadi, yang dinilai memiliki kedekatan dengan kelompok Ikhwanul Muslimin dan salafi-Wahabi dirasa tidak begitu lihai dalam menjaga kesetabilan dan perekonomian Yaman pasca tumbangnya Ali Abdullah saleh. Oleh sebab itulah kemudian, di tahun 2014 M, kelompok bersenjata al-Houthi yang disokong kuat oleh mantan Presiden Ali Abdullah Saleh, berusaha melakukan kudeta dengan menyerbu pusat-pusat pemerintahan dan pusat berita yang berkedudukan di kota
San'a. Aksi perlawanan yang dilakukan oleh al-Houthi terhadap pemerintahan Abdurrabuh Manshur Hadi ini ternyata menuai aksi protes yang begitu kuat dari banyak negara terutama Arab Saudi yang menjadi tetangga Yaman dan sekaligus menjadi ketua Organisasi Kerjasama Negara Teluk.

Penelitian ini mencoba memperlihatkan fakta yang berbeda tentang perang yang terjadi di Yaman antara al-Houthi dengan koalisi Arab Saudi, yang selama ini dianggap sebagai perang sekterian ataupun sikap koalisi Arab Saudi guna mempertahankan pemerintahan Abdurrabuh yang terpilih secara demokratis. Hal tersebut dikarenakan munculnya beragam spekulasi dan opini yang mencoba menjelaskan akar konflik di Yaman dengan menampakkan persoalanpersoalan ideologi sebagai pemicu utama terjadinya konflik. Akan tetapi, pada tulisan ini, peneliti mencoba memaparkan dan menampakkan sesuatu yang terlepas dari unsur ideologi semata. Tulisan ini, juga berusaha membandingkan tentang dalih menyelamatkan pemerintahan yang terpilih secara konstitusional sebagaimana yang digaungkan oleh Arab Saudi dalam melancarkan penyerangan terhadap alHouthi dengan kebijakan Arab Saudi di negara lain yang memiliki corak konflik yang hampir sama dengan Yaman. Akan tetapi, Arab Saudi malah memperlihatkan sikap yang berbeda dengan memberikan sokongan kepada oposisi. Hal itu tercermin dari apa yang ditampakkan oleh Arab Saudi terhadap beberapa negara yang berkonflik di Timur Tengah, seperti Suriah dan Libya (Darmiko Suhendra, 2019).

Dari gambaran perbandingan tersebut, maka peneliti melihat sesuatu kejanggalan yang sangat penting untuk ditelusuri tentang kebijakan Arab Saudi dan koalisinya dalam memutuskan untuk menyerang kelompok al-Houthi yang di dalam kasus konflik Yaman sebagai oposisi dari pemerintahan resmi secara konstitusional.

Data yang digunakan oleh peneliti di dalam tulisan ini bersumber dari buku, 
media masa, dan jurnal serta rekaman pengalaman peneliti yang langsung merasakan proses terjadinya konflik di Yaman antara koalisi yang dipimpin oleh Arab Saudi dengan kelompok al-Houthi. Pemilihan data ini, berdasarkan kesesuaian dengan fakta dan realita yang terjadi di Yaman dalam kemasan analitis yang dapat dipertanggungjawabkan secara akademik.

Adapun penelitian terdahulu yang memiliki kesamaan pembahasan dengan judul yang diteliti penulis, di antaranya:

Penelitian yang dilakukan oleh Jeremy M. Sharp dengan judul "Yemen: Civil War and Regional Intervention". Penelitian ini menyoroti faksi-faksi yang bertikai di Yaman yang disebabkan oleh perebutan kekuasaan dan wilayah, selain itu juga membahas tentang intervensi beberapa negara di kawasan Timur Tengah terhadap perang yang terjadi di Yaman. Penelitian ini juga menaruh perhatian terhadap dampak negatif yang ditimbulkan karena peperangan, terutama tingginya angka kematian dan kelaparan (Jeremy M. Sharp, 2021: 03).

Penelitian yang dilakukan oleh Helen Lackner dan Raiman al-Hamdani yang berjudul "Talking to the Houthis: How Europeans can promote peace in Yemen". Penelitian ini menganalisis mengenai dominasi kelompok al-Houthi yang semakin menguat di Yaman. Hal tersebut ditandai dengan dikuasinya sebagian besar wilayah Yaman bagian utara dan berhasil membentuk pemerintahan di Sana'a, meskipun dunia internasional tidak mengakuinya. Penelitian ini juga membahas tentang keterlibatan diplomatik Eropa dalam proses usaha memediasi beberapa kelompok yang bertikai di Yaman (Raiman al-Hamdani dan Helen Lackner, 2020: 10).

Penelitian yang dilakukan oleh Ashiya Parveen dengan judul "The Yemen Conflict: Domestic and Regional Dynamics". Penelitian ini menganalisis mengenai konflik yang berkepanjangan di Yaman, tidak lepas dari kuatnya pengaruh negara-negara di kawasan terutama Iran dan Arab Saudi. Penelitian ini melihat bahwa perdamaian di Yaman akan terbentuk apabila Arab Saudi dan Iran berhasil menemukan kesepakatan damai. Akan tetapi, apabila kedua negara tersebut tetap bersitegang maka akan sulit untuk menggapai perdamaian di Yaman (Ashiya Parveen, 2019: 06).

Penelitian yang dilakukan oleh Alvis Rahman Bhasuki, dkk, dengan judul "Perang Saudara di Yaman: Analisis Kepentingan Negara Interventif dan Prospek Resolusi Konflik". Dalam penelitian ini lebih menyoroti tentang intervensi negara-negara lain dalam konflik Yaman sebagai penentu terhadap kesetabilan konflik Yaman, ketika negaranegara tersebut mampu menemukan titik kesepakatan maka akan berdampak pada terciptanya perdamaian di Yaman (Alvis Rahman Bhasuki, dkk, 2019: 06).

Penelitian yang dilakukan oleh Ahmad Naufal Farras, yang berjudul "Balance of Power Dalam Intervensi Arab Saudi Pada Konflik Yaman Yang Terjadi Pasca Arab Spring". Penelitian ini menyimpulkan bahwa intervensi Arab Saudi dalam konflik Yaman adalah jawaban dari dorongan dunia internasional untuk menyelamatkan pemerintahan Abdurrabuh Manshur Hadi. Penelitian ini juga menyimpulkan bahwa intervensi Arab Saudi ialah sebagai penyeimbangan terhadap kekuatan Iran yang membantu kelompok al-Houthi di Yaman, karena hal tersebut bisa memberikan ancaman terhadap keamanan dan kedaulatan Arab Saudi (Ahmad Naufal Farras, 2020: 01) .

Begitu juga dengan penelitian yang dilakukan oleh Sigit Priambodo, dengan judul penelitian "Motif Intervensi Arab Saudi Terhadap Perang Saudara di Yaman". Dalam penelitian ini belum terlihat sebuah ketegasan secara pasti tentang penjelasan mengenai motif intervensi Arab Saudi, meskipun dalam penjelasannya lebih mengarah kepada permasalahan sekterian Sunni-Syi'ah dan lebih mengarahkan kepada keinginan Arab Saudi untuk membantu pemerintahan Abdurrabuh Manshur Hadi, serta ingin mengembalikan kesetabilan Yaman secara politik (Sigit Priambodo, 2017: 01). 
Berdasarkan beberapa penelitian di atas, peneliti belum menemukan hasil yang persis sama dengan apa yang diangkat penulis dalam artikel ini. Sehingga dari itu, penulis bertujuan memberikan perspektif baru mengenai konflik yang terjadi di Yaman antara kelompok al-Houthi dengan koalisi Arab Saudi.

\section{B. Metodologi}

Penelitian ini menggunakan metode kualitatif. Penelitian dengan metode kualitatif memiliki tujuan untuk mengembangkan kepekaan konsep serta penggambaran realitas yang tidak bersifat tunggal (Muhammad Idrus, 2009). Apabila dilihat secara teoritis, metode kualitatif bertolak dengan langkah mendefinisikan konsep yang bersifat umum, yang di dalamnya terjadi perubahan yang disebabkan hasil penelitian sehingga variabel bisa merupakan produk atau hasil (Muhammad Idrus, 2009).

Metode kualitatif dilakukan dengan langkah menganalisis data-data yang sudah dikumpulkan, disusun, dan kemudian dianalisis dengan melihat keterkaitan antara faktor-faktor yang mempunyai keterkaitan dengan fenomena yang sedang diteliti suapaya fenomena tersebut bisa mudah dicerna, baik itu dari segi penyebab terjadinya fenomena tersebut sampai dengan langkah-langkah untuk penyelesaiannya (Ahmad Fuadi, 2017: 01).

Dalam artikel ini peneliti menggunakan metodologi deskriptif kualitatif, penelitian deskriptif kualitatif dalam penelitian ini akan dilakukan dengan beberapa tahapan di antaranya mengangkat masalah, mengajukan pertanyaan penelitian, mengumpulkan data yang relevan, menganalisis data, dan menjawab pertanyaan penelitian.

\section{Hasil dan Pembahasan}

\section{Syi'ah Zaidiyah}

Ahmad Sahide dalam artikelnya yang berjudul "Konflik Syi'ah-Sunni Pasca-the Arab Spring", menyampaikan bahwa ada empat ciri-ciri ekslusif
Syi' isme: 'ismah (Imam terhindar dari perbuatan dosa), Mahdisme (mempercayai akan datangnya Imam Mahdi sebagai imam terakhir yang akan menegakkan keadilan). Dalam Syi'ah Itsna Asyariah, meyakini bahwa Imam Mahdi merupakan imam kedua belas, Syi'ah Ismailiyah menjadikan Imam Mahdi sebagai imam ketujuh, sedangkan dalam Syi'ah Zaidiyah menjadikan Imam Mahdi sebagai Imam ke-enam; taqiyyah (melindungi diri), taqiyyah merupakan salah satu strategi politik kelompok Syi'ah untuk melindungi kepentingan atau keselamatan diri maupun kelompok mereka bila dalam keadaan terancam. Hal tersebut dilakukan karena kaum Syi'ah beranggapan bahwa diri mereka selalu dijadikan objek kekerasan dan diskriminasi yang dilakukan oleh kelompok Sunni; dan raj'ah (kembalinya Imam Mahdi sebagai penegak keadilan) setelah lama dalam penantian (Ahmad Sahide, 2013: 12).

Syi'ah Zaidiyah adalah salah satu golongan Syi'ah yang dinisbatkan namanya kepada Imam Zaid bin Ali (67$122 \mathrm{H}=686-740 \mathrm{M}) . \quad$ Nama panjangnya ialah Zaid bin Ali Zainal Abidin bin AlHusain bin Ali bin Abi Thalib Al-Qurasyi Al-Hasyimi Al-'Alawi Abu Al-Husain alMadani. Imam Zaid dilahirkan di kota Madinah al-Munawwarah (Sayyid Ahmad Sayyid, 2017).

Imam Zaid berdomisili di Kuffah. Imam Zaid dikenal pada masanya sebagai seseorang yang memiliki jiwa pemberani, berpengetahuan luas, sangat disegani oleh masyarakat di kala itu, dan pantang menyerah dalam meperjuangkan dakwahnya. Imam zaid memiliki hubungan yang cukup dekat dengan Washil bin Atha' dan juga sering berdiskusi dengan Abu Hanifah di Irak. Imam Zaid pernah melakukan penentangan terhadap Khalifah Umayyah dengan memobilisasi para pendukungnya di Kufah. Akhirnya, beliau wafat dalam pertempuran melawan Yusuf bin Umar, seorang gubernur yang diangkat oleh Khalifah Hisyam untuk daerah Irak pada tahun 122H (Aminun P. Omolu, 2012: 12). 
Jika dibandingkan dengan kelompok Syi'ah lainnya, Syi'ah Zaidiyah bisa dikatakan paling moderat. Syi'ah Zaidiyah, juga memiliki kedekatan dengan Ahlussunnah Wal Jama'ah. Hal itu dikarenakan mereka tidak mengkultuskan para imam memiliki derajat yang istimewa dari Allah sebagaimana halnya para Nabi dan Rasul. Hanya saja mereka berpendapat bahwa para imam adalah manusia yang mulia setelah Nabi Muhammad. Kelompok ini juga sama sekali tidak melaknat para sahabat Nabi, terutama mereka yang dibai'at oleh Ali ibnu Abi Thalib, mereka juga mengakui kepemimpinan mereka. Zaidiyah berpendapat bahwa Sahabat Ali ibnu Abi Thalib adalah orang yang paling pantas menjadi pemimpin setelah kewafatan Nabi Muhammad SAW. Mereka berpendapat Sayyidina Ali memiliki sifat dan ciri-ciri yang lebih dekat dengan apa yang pernah disampaikan oleh Nabi Muhammad SAW. Sementara untuk imam setelah Sayyidina Ali yang lebih berhak ialah garis keturunan Nabi dari Sayyidah Fatimah. Akan tetapi, apabila sifat-sifat tersebut tidak terpenuhi, maka bolehlah yang lain menduduki jabatan imam. Imam bentuk kedua ini dikenal dengan istilah alMafdhul. Berdasarkan alasan ini, Syi'ah Zaidiyah dapat menerima para Khulafa arRasyidin selain Ali ibnu Abi Thalib. Di samping itu, dari segi hukum Imam Zaidiyah tidak jauh berbeda dengan imam Ahlussunnah. Dalam metode istinbath alhukum juga tidak jauh berbeda dengan para ulama yang hidup di masanya, seperti: Abu Hanifah, Utsman Al-Bitti, Az-Zuhri, Ibnu Abi Laila, dan lain sebagainya baik itu ulama Madinah maupun Irak (Ahmad Atabik, 2015: 12).

Setelah wafatnya Imam Zaid, para pengikutnya terpecah menjadi beberapa golongan, diantaranya: al-Jarudiyah, asSulaimaniyah (al-Jaririyah), al-Batariyah (as-Shalihiyah), an-Nu'aimiyah, alHusainiyah, al-Mukhtara'ah, alMuthrafiyah, as-Salimiyah, al-Qasimiyah, al-Muayyidiyah, al-Ya'kubiyah, alMutabarriun, an-Nashiriyah, alHadawiyah, al-'Aqabiyah, asShabaahiyah, dan al-Houthiyah. Sebagian besar kelompok Zaidiyah pada saat ini berpegang teguh terhadap ajaran Imam Zaid bin Ali, kelompok Zaidiyah secara Fiqih pada umumnya mengikuti mazhab al-Hadawi, yang dinisbatkan kepada Imam Al-Hadi Yahya bin Al-Husain bin AlQasim Ar-Rassi (298H). Kelompok Zaidiyah saat ini, sebagian besarnya terdapat di Yaman, yang dikenal dengan sebutan (az-Zuyud). Az-Zuyud juga adalah sebutan dari beberapa suku di Yaman, seperti: Bakil dan Hasyid. Akan tetapi, mereka mengikuti Mazhab Syafi'i (Sayyid Ahmad Sayyid, 2017).

\section{Kelompok Bersenjata Al-Houthi}

Al-Houthi adalah gerakan politik agama bersenjata yang mengikuti ajaran Syi'ah Zaidiyah, kelompok ini muncul sejak tahun 1982 M., dan terus eksis sampai saat ini dengan julukan "Tandzimu as-Syababu al-Mukmin" (Gerakan Para Pemuda Beriman), selain itu juga dikenal dengan julukan "Ansharullah" (Para Penolong Allah). Gerakan ini mendapatkan sokongan yang kuat dari Iran, Hizbullah, kelompok Syi'ah di Irak, dan juga mendapatkan dukungan yang kuat dari mantan Presiden Ali Abdullah Shaleh. Kelompok al-Houthi memiliki jumlah tentara yang cukup dramatis, yaitu sekitar setengah juta jiwa, dan jumlah ini adalah jumlah tentara terbesar bila dibandingkan dengan jumlah tentara negara-negara di kawasan semenanjung Arab (Sayyid Ahmad Sayyid, 2017).

Kelompok al-Houthi pertama kali muncul di provinsi Sha'dah (Ashiya Parveen, 2019: 06). Adapun tokoh sentral dari gerakan ini adalah tiga orang bersaudara dan ayahnya, di mana mereka memiliki darah keturunan Nabi Muhammad. Mereka adalah Badruddin alHouthi, Husain al-Houthi, Abdul Malik al-Houthi, dan Yahya al-Houthi (Sayyid Ahmad Sayyid, 2017).

\section{Perlawanan Al-Houthi Terhadap Pemerintahan Abdurrabuh Manshur Hadi}

Pada paruh kedua tahun 2014, Presiden Hadi dihadapkan dengan tantangan yang cukup berat. Yaman pada 
saat itu berada dalam kondisi yang teramat sulit karena dihadapkan pada krisis fiskal. Pemerintah Yaman pada waktu itu berjuang untuk membayar gaji para pegawai dan hutang yang sudah jatuh tempo sementara perekonomian terus mengalami keterpurukan yang disebabkan produksi minyak terganggu akibat konflik. Akhirnya, sebuah pertemuan dilakukan di Riyadh pada bulan Juli 2014. Hadi pada saat itu, ditawari bantuan sebesar 2 miliar dollar AS dengan syarat memangkas subsidi bahan bakar di bawah pengawasan IMF dan Bank Dunia. Pemerintah Yaman menerima tawaran tersebut, dan bahkan justru memangkas subsidi melebihi saran dari kedua lembaga internasional tersebut. Pejabat pemerintahan mencoba mengkalkulasi pemotongan subsidi dapat menimbulkan keresahan publik yang dapat dieksploitasi oleh pihak oposisi (Ahmad Fuadi, 2017: 01).

Lonjakan harga bahan bakar dan bahan makanan lainnya, memicu masyarakat Yaman untuk turun ke jalan guna melakukan aksi protes di kota San'a dan kota-kota lainnya. Abdul Malik alHouthi, pemimpin al-Houthi pada saat itu memberikan sebuah pernyataan, apabila harga minyak tidak dikembalikan ke harga sebelumnya, maka dia dan pengikutnya akan melakukan perlawanan untuk menggulingkan pemerintahan Abdurrabuh Manshur Hadi. Dari awal pemerintahan Abdurrabuh, kelompok al-Houthi memang terus mencari celah kesalahan pemerintah untuk digunakan sebagai alasan melakukan perlawanan terhadap pemerintahan Yaman. Pada tanggal 17 Agustus 2014 M., Abdul Malik muncul di saluran televisi al-Masira, saluran televisi al-Houthi. Ia mengumumkan bahwa para pendukungnya akan memasuki Sana'a esok harinya dengan mendirikan tenda dan akan melakukan protes setiap harinya hingga apa yang menjadi tuntutan mereka dapat dipenuhi. Para demonstran akan melakukan aksi damai, namun apabila mereka diserang, maka kelompok alHouthi tidak akan tinggal diam (Ahmad Fuadi, 2017: 01).

\section{Meletusnya Peperangan Antara Pasukan Al-Houthi dan Pemerintah Yaman}

Konflik antara kelompok al-Houthi dan suku-suku Sunni di Yaman Utara terus menyebar ke wilayah lainnya, termasuk dengan Bani al-Ahmar yang membawahi beberapa suku di provinsi Sana'a di pertengahan tahun 2014. Setelah beberapa minggu melangsungkan protes terhadap pemerintahan Abdurrabuh yang membuat pemangkasan terhadap subsidi bahan bakar, pasukan al-Houthi menyerang pasukan Angkatan Darat Yaman yang berada di bawah komando Jenderal Ali Muhsin al-Ahmar. Dalam peperangan yang berlangsung tidak lama, para pejuang al-Houthi berhasil menguasai Sana'a, ibu kota Yaman, tepatnya pada September 2014. Al-Houthi memaksa Abdurrabuh bernegosiasi tentang kesepakatan untuk mengakhiri kekerasan, yang ditandai pengunduran diri Abdurrabuh dan al-Houthi memperoleh pengaruh yang sebelumnya tidak pernah terjadi dengan menguasai institusi dan politik negara (Mata Mata Politik, 2021: 04).

Drama kekuasaan menjadi sebab pengunduran diri Presiden Abdurrabuh Manshur Hadi beserta para menterinya. Kepemimpinan politik al-Houthi kemudian mengumumkan pembubaran parlemen serta pembentukan Komite Revolusi guna memerintah negara pada tanggal 6 Februari 2015. Tepat pada 21 Februari, satu bulan setelah al-Houthi menahan Abdurrabuh di kediamannya di ibu kota Sana'a, Abdurrabuh menyelinap keluar dari ibu kota dan melarikan diri ke kota Aden. Dalam sebuah pidato yang disiarkan stasiun televisi dari kota asalnya (Aden), Abdurrabuh menyatakan bahwa pengambilalihan al-Houthi tidak sah dan mengindikasikan bahwa dirinya tetap menjadi presiden konstitusional Yaman (Mata Mata Politik, 2021: 04).

Pasukan keamanan Yaman terpecah menjadi dua bagian, satu bagian membela kaum Sunni yang di mana menjadi poros pemerintahan utama di kala itu, sementara sebagian yang lainnya memilih untuk bergabung dengan kelompok al-Houthi 
yang notabenenya adalah kaum Syi'ah. Presiden Yaman, Abdurrabuh Manshur Hadi banyak mendapatkan sokongan dari penduduk Yaman bagian selatan yang secara umumnya berpaham Sunni (Sigit Priambodo, 2017: 01). Di wilayah Yaman Utara, kelompok al-Houthi juga mendapatkan perlawanan yang sengit dari beberapa suku baik Sunni maupun Syi'ah Zaidiyah yang tidak menerima tanah atau wilayahnya dimasuki oleh kelompok alHouthi. Sehingga dari situ, kelompok alHouthi terpecah konsentrasi karena menghadapi dua arus perlawanan sekaligus, yaitu perang melawan militer yang mempertahankan pemerintahan Abdurrabuh dan perang melawan berbagai suku yang menolak kedatangannya di beberapa wilayah.

Pesatnya perkembangan wilayah kekuasaan kelompok al-Houthi di Yaman Utara serta dikuasainya ibu kota Yaman, Sana'a, pada bulan September 2014, mampu menarik perhatian pemain-pemain regional besar yang memiliki kepentingan menjaga stabilitas Yaman dan akses ke wilayah perairan Selat Mandab. Jalur strategis ini menjadi motif bagi Arab Saudi di dalam melakukan intervensi terhadap Yaman, dikarenakan Selat Mandab yang ada di Yaman ini memiliki pengaruh yang sangat kuat terhadap jalur perdagangan Arab Saudi (Sigit Priambodo, 2017: 01).

Hal Itu tercermin dari setiap kapal yang bertolak atau datang dari Arab Saudi akan melewati selat tersebut, maka dari itu menguasai jalur strategis tesebut merupakan hal yang utama bagi Arab Saudi untuk melakukan intervensi terhadap Yaman (Sigit Priambodo, 2017: 01). Keikut sertaan Arab Saudi di dalam konflik Yaman, menyebabkan beberapa negara lain yang memiliki kepentingan di kawasan tersebut ikut serta dengan membentuk koalisi untuk melakukan serangan terhadap kelompok al-Houthi. Arab Saudi dan koalisinya berdalih untuk menyelamatkan pemerintahan Abdurrabuh Manshur Hadi yang dianggap sebagai pemerintahan Yaman secara sah berdasarkan konstitusional, namun hal tersebut hanyalah sebatas alasan belaka untuk mempermulus penyerangannya terhadap kelompok al-Houthi.

\section{Kuatnya Dominasi Al-Houthi di Yaman Pasca Arab-Spring}

Kelompok al-Houthi yang sebelumnya hanya berbasis di provinsi Sha'dah dan hanya memiliki pengikut yang juga terbatas di kalangan masyarakat yang ada di provinsi tersebut, lambat laun mencoba untuk memperluas jangkauan wilayahnya dengan membujuk kepalakepala suku yang ada di sekitarnya untuk bergabung dengan kelompok al-Houthi guna melakukan perlawanan terhadap pemerintahan Abdurrabuh Manshur Hadi yang dianggapnya sudah tidak mampu lagi menjaga kestabilan Yaman. Akan tetapi, al-Houthi juga mendapatkan perlawanan yang cukup sengit dari beberapa suku yang ada di beberapa provinsi Yaman begian utara, seperti halnya di provinsi Taiz, Ma'rib, Sana'a, Ib, dan beberapa provinsi lainnya.

Peneliti yang pada waktu itu sedang mengenyam pendidikan pada salah satu universitas di kota Hudaidah (kota pelabuhan terpenting di Yaman), ikut secara langsung merasakan bagaimana kecamuk peperangan yang terjadi, dari sejak bergulirnya Arab-Spring sampai pertengahan tahun 2015. Kelompok alHouthi, sebagai salah satu kelompok yang menganut paham Syi'ah Zaidiyah secara akidah, nampaknya sebagai salah satu daya tarik tersendiri yang mampu menjadi magnet untuk menggalang simpatisan dari rakyat Yaman yang notabenenya sekitar 45\%-50\% menganut Syi'ah Zaidiyah (Republika, Teguh Firmansyah, 2019: 12).

Satu demi satu pusat pemerintahan dan wilayah-wilayah penting Yaman mulai berada di bawah kendali al-Houthi, pergerakan yang bisa dibilang cukup akurat dan fantastis ini, ternyata dirasa menjadi sebuah ancaman bagi negara tetangga khususnya Arab Saudi. Betapa tidak, Al-Houthi merupakan kelompok yang secara terang-terangan menyatakan penentangannya terhadap Arab Saudi. Hal tersebut disinyalir karena kedekatan yang kuat antara al-Houthi dan Iran, yang mana 
Iran merupakan musuh bebuyutan Arab Saudi.

Dominasi yang begitu cepat dari alHouthi di Yaman, tidak lepas dari peran yang dimainkan oleh mantan Presiden Yaman Ali Abdullah Shaleh yang sebelumnya berhasil diturunkan dari kursi kepemimpinannya karena kuatnya tekanan dari negara-negara Teluk, terutama Arab Saudi yang mendapatkan respon positif dari Amerika Serikat dan Uni Eropa (Firmanda Taufiq, 2018: 05).

Berkuasa lebih dari tiga puluh tahun di Yaman, ternyata menjadikan Ali Abdullah Shaleh memiliki pengikut yang memiliki loyalitas tinggi dari kalangan militer Yaman. Latar belakang militer Shaleh juga menjadi salah satu kekuatan yang dimiliki mantan pemimpin diktator Yaman ini. Maka tidak heran bila alHouthi begitu cepat menguasai tempattempat strategis di Yaman. Hal tidak lain karena mendapatkan sokongan dari militer loyalis Ali Abdullah Shaleh.

\section{Sikap Arab Saudi Terhadap Dominasi Al-Houthi di Yaman}

Arab Saudi merupakan salah satu negara penghasil minyak mentah terbesar, dengan menempati urutan kedua di dunia (Jessica Claudia Mawikere, 2016: 10). Hal ini lantas menjadikan Arab Saudi menjalin hubungan dengan negara-negara industri, baik di daratan Eropa maupun Amerika Serikat. Sementara itu, secara georafis Yaman memiliki letak yang cukup strategis sebagai jalur perdagangan, mengingat di Semenanjung Arab terdapat dua jalur perdagangan laut yang sangat penting. Di selatan terdapat Selat Hormuz, yang saat ini di bawah kendali Iran, sedangkan di sebelah utara terdapat Selat Mandab (Babu al-Mandab), yang terletak di antara Yaman dan negara Tanduk Afrika (Somalia, Djibouti, dan Eritrea).

$$
\text { Selat Mandab, yang }
$$

menghubungkan antara Samudra Hindia dan Laut Mediterania untuk bisa memasuki daratan Eropa, dianggap menjadi jalur ekspor-impor yang sangat penting bagi negara-negara yang memiliki kepentingan di kawasan tersebut. Selat yang memiliki lebar $18 \mathrm{mil} \mathrm{ini,} \mathrm{menurut}$
Departemen Energi Amerika dianggap sebagai jalur minyak tersibuk keempat di dunia dan dianggap sebagai chake point transit minyak dunia (Puji Taliasih, 2016).

Sementara itu, keadaan Yaman yang tidak stabil dan di sisi lain pengaruh al-Houthi yang terus menguat di Yaman menjadi ancaman bagi Arab Saudi dan negara-negara lain yang memiliki kepentingan di jalur perdagangan tersebut (Bab al-Mandab). Hal itu disebabkan karena kedekatan hubungan antara alHouthi dan Republik Islam Iran (RII). Iran yang secara mantap mengendalikan Selat Hormuz, dianggap sebagai sebuah ancaman apabila al-Houthi menguasai sepenuhnya pemerintahan di Yaman, maka secara tidak langsung Selat Mandab pun akan jatuh di bawah kontrol Iran. Hal ini tentunya menyebabkan Arab Saudi dan negara-negara yang bersebrangan dengan Iran mengambil langkah pasti untuk menyempitkan ruang gerak al-Houthi yang dianggap berada di bawah pengawasan Iran.

Al-Houthi dan Iran memiliki ideologi yang sama secara akidah, yaitu akidah Syi'ah. Hal ini, juga sebagai salah satu sentimen bagi Arab Saudi yang mayoritas menganut Salafi-Wahabi. Salafi-Wahabi dengan beberapa Ulamanya secara tegas sering mengeluarkan fatwa tentang sesatnya kaum Syi'ah. Hal ini juga menjadi salah satu dalih yang digunakan Arab Saudi untuk memperoleh dukungan dari masyarakatnya dan negara-negara Sunni untuk menghalalkan serangan militer terhadap kelompok al-Houthi di Yaman.

Tepat pada tanggal 29 April 2015, Menteri Dalam Negeri Arab Saudi, Muhammad bin Nayef memberikan pernyataan resminya untuk melakukan serangan militer terhadap al-Houthi di Yaman. Serangan pertama diarahkan ke wilayah perbatasan Jizan yang mengakibatkan satu orang tentara perbatasan dan dua orang warga sipil Yaman meninggal dunia (Ahmad Fuadi, 2017: 01). Serangan koalisi Arab Saudi ini telah memakan nyawa ratusan ribu dari warga sipil Yaman. Termasuk yang 
menjadi mayoritas korban adalah golongan perempuan dan anak-anak.

Andrew Coburn, seorang wartawan senior majalah Harper's yang terbit di Amerika mengatakan:

"Pemerintah Arab Saudi yang beraliran Sunni merasa ketakutan menyaksikan kekuatan kelompok bersenjata al-Houthi yang beraliran Syi'ah, yang mendapatkan sokongan dari Iran, dan sekaligus merupakan musuh besar Arab Saudi. Arab Saudi memiliki ketakutan bahwa Iran akan membangun pangkalan militernya di perbatasan bagian selatannya. Tapi hal ini sebenarnya hanyalah sebuah ketakutan yang tidak beralasan, alias paranoia, karena Iran sendiri tidak memiliki maksud seperti itu. Iran memang memilki hubungan yang sangat erat dengan kelompok al-Houthi yang merupakan kelompok yang berpaham Syi'ah yang mendominasi Yaman bagian utara

(VOAIndonesia, 2019: 12)."

Peneliti melihat bahwa apabila Yaman jatuh ke tangan al-Houthi yang berada di bawah kendali Iran, maka Arab Saudi dan mayoritas negara kawasan Teluk akan merasa terhimpit baik secara politik, ekonomi, dan juga sekaligus mengurangi pengaruh serta peran penting Saudi Arabia untuk bisa mengendalikan pemerintahan Yaman guna memuluskan berbagai macam kebijakan Arab Saudi terhadap negara miskin yang kaya akan sumber daya mineral itu.

\section{Komparasi Kebijakan Arab Saudi dalam Konflik Suriah dan Yaman}

Dalih yang begitu kuat dari Arab Saudi dan koalisinya dalam intervensinya di Yaman, ialah untuk menyelamatkan pemerintahan Abdurrabuh Manshur Hadi yang terpilih secara konstitusional. Dalih yang diperlihatkan oleh Arab Saudi dan koalisinya ini ternyata tidaklah senada dengan apa yang dilakukan Arab Saudi dan koalisinya terhadap Suriah.

Intervensi Arab Saudi dalam konflik Suriah, merupakan salah satu kepentingan nasional Arab Saudi yang harus diwujudkan. Arab Saudi dan Suriah merupakan dua negara Arab yang bersaing amat ketat dalam memperebutkan kursi kepemimpinan di Liga Arab serta ditambah dengan meningkatnya pengaruh Iran yang amat kuat di kawasan Timur Tengah adalah suatu ancaman yang nyata bagi Arab Saudi. Maka dari itu, dengan mengintervensi konflik yang terjadi di suriah serta melengserkan Bassar AlAssad diharapkan bisa menjawab kepentingan Arab Saudi, serta menyingkirkan daftar negara pendukung setia Iran di Timur Tengah (Oktana Karbesi, 2016).

Selain hal tersebut, Arab Saudi memiliki ambisi yang begitu besar untuk menancapkan taringnya di Suriah, terutama dalam aspek perekonomian. Akan tetapi, Arab Saudi memperoleh kegagalan untuk menjadikan Suriah sebagai mitra ekonominya. Keinginan utama Arab Saudi ialah keinginannya untuk menjadikan Suriah sebagai jalur penting perdagangan minyak dengan jalan memasang pipa untuk memudahkan distribusi minyak ke beberapa negara yang menjadi konsumen Arab Saudi. Akan tetapi, keinginan Arab Saudi tersebut harus kandas karena penolakan kuat yang ditunjukkan oleh Presiden Suriah Bashar al-Asad (Mustahyun, 2017: 12).

Dalam konflik Suriah, jika diamati secara sepintas maka akan nampak pemicu kuatnya adalah karena keinginan yang kuat dari masyarakat Suriah untuk melakukan perubahan dalam sistem pemerintahan Suriah yang selama ini dianggap otoritarianisme. Hal ini, bisa dilihat dari simbol yang diperlihatkan dalam proses bergulirnya Arab Spring, yaitu keinginan masyarakat-negara mulai dari Tunisia hingga menyebar di negaranegara lain untuk menerapkan sistem demokrasi. Akan tetapi, jika ditelaah lebih dalam, maka akan nampak sesuatu yang berbeda. Suriah pada dasarnya ialah salah satu negara di kawasan Timur Tengah yang memiliki kekuatan militer dan intelejen yang tidak bisa dipandang sebelah mata, selain itu Suriah di bawah kepemimpinan Bashar al-Asad, selalu menampakkan sikap perlawanannya 
terhadap Israel yang notabene adalah sekutu kuat dari Amerika Serikat di kawasan Timur Tengah. Keadaan Suriah yang seperti demikian menjadikan negaranegara seperti Israel, NATO, Amerika Serikat, Saudi Arabia, Turki, dan Qatar melakukan langkah dengan mendukung oposisi (A. Muchaddam Fahham dan A.M. Kartatmaja, 2014: 06). Padahal dalam kenyataan yang terjadi, oposisi yang mendapatkan dukungan dari negaranegara tersebut sangat bertentangan dengan simbol yang diangkat dalam proses bergulirnya Arab Spring, yaitu keinginan dalam menerapkan sistem pemerintahan baru yang dikenal dengan sistem demokrasi. Adapun kelompokkelompok yang disokong oleh Arab Saudi dan yang lainnya ialah kelompokkelompok seperti Jabhah an-Nushroh, alQaida, dan beberapa kelompok lainnya yang bisa terbilang ekstrim dan bahkan kelompok teroris, yang sangat jauh dari kata demokrasi.

Dari paparan di atas memperlihatkan bahwa sikap negaranegara yang sering ikut campur dalam pergulatan konflik di Timur Tengah menampakkan sikap yang tidak konsistenan. Jika di Yaman, Arab Saudi dan yang lainnya mendukung pemerintahan yang digulingkan oleh kelompok al-Houthi dengan dalih menyelamatkan pemerintahan yang terpilih secara konstitusional. Akan tetapi, dalam kasus Suriah negara-negara tersebut malah memposisikan diri mereka pada posisi yang berbanding terbalik dari apa yang menjadi dalih mereka dalam mengintervensi Yaman.

\section{Kesimpulan}

Setelah tumbangnya Ali Abdullah Shaleh dari tampuk kepemimpinannya, suku-suku dan kelompok bersenjata di Yaman yang sebelumnya dapat ditundukkan berubah seketika dengan melakukan pemberontakan dan perlawanan terhadap pemerintahan Abdurrabuh Manshur hadi yang dianggap tidak bisa mengendalikkan keadaan di Yaman. Salah satu kelompok yang paling getol melakukan penentangan adalah kelompok al-Houthi yang berbasis di provinsi Sha'dah. Hal tersebut terbukti dari aksi protes yang dilakukan oleh Abdul Malik al-Houthi yang pada waktu itu menjadi ketua dari kelompok tersebut. Aksi protes yang dilakukan oleh kelompok al-Houthi ternyata tidak terhenti dengan sebuah protes mulut, melainkan mereka melakukan serangan bersenjata dengan menyasar militer Angkatan Darat Yaman serta melakukan penyerangan terhadap tempat-tempat vital pemerintahan yang terdapat di ibu kota Yaman, Sana'a.

Arab Saudi, sebagai salah satu negara yang memiliki taring di Timur Tengah, melihat sebuah ancaman besar yang berada tepat di sampingnya. Ancaman tersebut ialah tumbuhnya kekuatan kelompok Houthi di negara tetangganya, yaitu Yaman. Arab Saudi ternyata tidak tinggal diam melihat ancaman tersebut, hal itu terbukti dengan penggalangan kekuatan yang dilakukan oleh Arab Saudi dengan membangun koalisi yang kemudian melancarkan serangan terhadap kelompok Houthi dengan dalih menyelamatkan pemerintahan Abdurrabuh Manshur Hadi yang dianggapnya dirampas secara paksa oleh kelompok al-Houthi.

Penulis dalam penelitian ini menyimpulkan bahwa serangan Arab Saudi berserta koalisinya ke Yaman, tidaklah semata-mata karena ingin mempertahankan pemerintahan Abdurrabuh Manshur Hadi dan juga bukan semata-mata masalah sekterian antara Sunni-Syi'ah, melainkan lebih kepada permasalahan peta politik Arab Saudi di Timur Tengah serta lebih kepada permasalahan ekonomi, dan pengaruh Arab Saudi di Timur Tengah.

\section{DAFTAR PUSTAKA}

Ahmed, Niaz. (2019). Yemeni Civil War: Causes, Consequenses and Prospects. Jurnal Dinamika Pemerintahan, Vol. 02, No. 02, Agustus 2019.

Atabik Ahmad. (2015). Melacak Historisitas Syi'ah: Asal Usul, 
Perkembangannya, dan AliranAlirannya. Fikrah: Jurnal Aqidah dan Studi Keagamaan, Vol 3, No. 2, Desember 2015.

Belekubun, Rivaldo. (2019). Sejarah, Pengertian, dan Relevansi Sistem Balance of Power Sebagai Mekanisme Keamanan dalam Skema Perpolitikan Internasio. Jurnal Politik dan Keamanan Internasional.

Blumberg, Fabian. (2019). The Yemen War: Actors, Interests and the Prospects of Negotiations. Regional Programme Gulf State: Konrad Adenauer Stiftung, Oktober 2019.

Fahham A. Muchaddam dan A.M. Kartatmaja. (2014). Konflik Suriah: Akar Masalah dan Dampaknya. Jurnal Politica, Vol. 5 No. 1 Juni 2014

Firmansyah, Teguh. (2016). REPUBLIKA .CO.ID. Ini Peta Populasi Syi'ah di Timur Tengah, from: https:// www.googl e.com/amp/s/m.republika.co.id/amp /o0ijv1377. Diakses Pada Pukul 15:00, 25 Desember 2019.

Fuadi, Ahmad. (2017). Kepentingan Arab Saudi Menghentikan Gerakan Pemberontak Houthi. Jurnal Demokrasi dan Otonomi Daerah, Vol. 15, No. 1, Januari 2017.

Idrus, Muhammad. (2009). Metode Penelitian Ilmu Sosial: Pendekatan Kualitatif dan Kuantitatif. Jakarta: Penerbit Erlangga.

Jessica Claudia Mawikere. (2016). Implikasi Kuota Produksi Minyak Organization of the Petroleum Exportingn Countries (OPEC) dengan Kebijakan Keanggotaan dan Harga Bahan Bakar Minyak Pemeritah Indonesia Tahun 2008. Jurnal Analisis Hubungan Internasional, Vol. 5 No. 3, Oktober 2016.

Karbesi, Oktana. (2016). Kebijakan Intervensi Arab Saudi dalam
Konflik Suriah. Yogyakarta. Yogyakarta: Fakultas Ilmu Sosial dan Ilmu Politik Universitas Pembangunan Nasional Veteran.

Kartatmaja A.M. dan Fahham, A. Muchaddam. (2014). Konflik Suriah: Akar Masalah dan Dampaknya. Jurnal Politica, Vol. 05, No. 01, Juni 2014.

Lackner, Hellen dan Al-Hamdani Raiman. (2020). Talking to the Houthis: How Europeans can Promote Peace in Yemen. European Council on Foreign Relations, 14 Oktober 2020 .

Matamatapolitik. (2021). Awal Mula Perang Yaman: Mengapa Konflik Terus Memburuk?, from: https://www.mata matapolitik.awalmula-perang-yaman. Diakses pada 16 Mei, 2021.

Mustahyun. (2017). Rivalitas Arab Saudi dan Iran di Timur Tengah Pada Arab Spring Suriah Tahun 20112016. Jurnal Islamic World and Politics, Vol. 1. No. 1, JuliDesember 2017.

Naufal, Ahmad Farras. (2020). Balance of Power Dalam Intervensi Arab Saudi Pada Konflik Yaman yang Terjadi Pasca Arab Spring. Journal of International Relations, Vol. 06, No. 01, 2020.

Parveen, Ashiya. (2019). The Yemen Conflict: Domestic and Regional Dynamics. West Asia in Transition, Vol. 02, Juni 2019. From: https://www.researchgate.net/public ation/334119925_The_Yemen_Con flict_Domestic_and_Regional_Dyn amics. Diakses pada 04 Oktober 2021.

P. Omolu Aminun. (2012). Syi'ah Zaidiyah: Konsep Imamah dan Ajaran-Ajaran Lainnya. Jurnal Studia Islamika, Vol. 9, No, 2, Desember 2012.

Priambodo, Sigit. (2017). Motif Intervensi Arab Saudi Terhadap Perang 
Saudara di Yaman. Jurnal Analisis Hubungan Internasional, Vol. 6 No. 1, Januari , 2017.

Rahman, Alvis Bhashuki, dkk. (2019). Perang Saudara di Yaman: Analisis Kepentingan Negara Interventif dan Prospek Resolusi Konflik. Jurnal Ilmu Politik dan Komunikasi, Vol. IX, No. 01, Juni 2019.

Sahide, Ahmad. (2013). Konflik Syi'ahSunni Pasca-the Arab Spring. Jurnal Kawistara, Vol. 03, No. 03, Desember 2013.

Sahide, Ahmad. (2017). The Arab Spring and Democratization; Why is Syria Diferent?. Jurnal Sospol, Vol. 03, No. 02, Juli-Desember 2017.

Sayyid, Ahmad Sayyid. (2017). AlHouthiuun Rafhidhatu Az-Zaidiyiin. Jurnal Islam Bilimleri Arastirmalari Dergisi: 2017.

Suhendra, Darmiko. (2019). Relasi Timur dan Barat dalam Permasalahan
Konflik di Suriah. Jurnal Hikmah, Vol. XV, No. 01, 2019.

Taliasih, Puji. (2016). Dukungan Arab Saudi Terhadap Manshur Hadi Dalam Menghadapi Pemberontak Syi'ah Houthi Di Yaman Tahun 2012-2015. Jurnal International Society, Vol. 3 No. 2, 2016.

Taufiq, Firmanda dan Lalu Wahyu Putra Utama. (2018). Hegemoni Amerika Serikat Terhadap Arah Kebijakan Arab Saudi dalam Konflik Yaman Pasca Arab Spring 2011-2017. Jurnal ICMES, Vol. 1, No. 1, Mei 2018.

VOAIndinesia. (2017). Perang Saudara dan Campur Tangan Arab Saudi di Yaman. From: https://www.google.com/amp/s/ww w.voaindonesia.com/amp/3861609. html. Diakses pada 25 Desember 2019. 